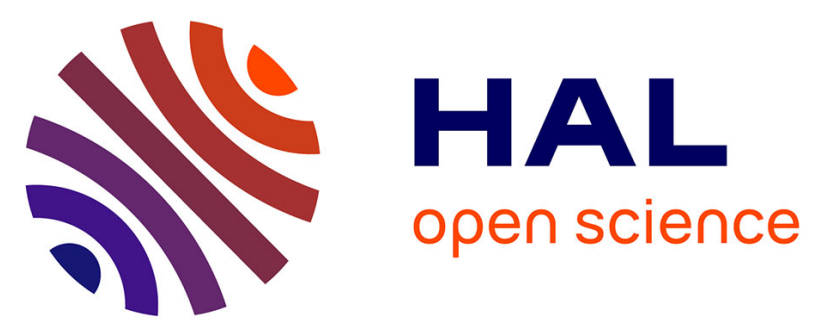

\title{
beta-eudesmol, a sesquiterpene from Teucrium ramosissimum, inhibits superoxide production, proliferation, adhesion and migration of human tumor cell
}

Mohamed Ben Sghaier, Mohamed Mousslim, Alessandra Pagano, Youssef Ammari, José Luis, Hervé Kovacic

\section{To cite this version:}

Mohamed Ben Sghaier, Mohamed Mousslim, Alessandra Pagano, Youssef Ammari, José Luis, et al.. beta-eudesmol, a sesquiterpene from Teucrium ramosissimum, inhibits superoxide production, proliferation, adhesion and migration of human tumor cell. Environmental Toxicology and Pharmacology, 2016, 46, pp.227 - 233. 10.1016/j.etap.2016.07.019 . hal-01474963

\section{HAL Id: hal-01474963 \\ https://hal-amu.archives-ouvertes.fr/hal-01474963}

Submitted on 2 Mar 2017

HAL is a multi-disciplinary open access archive for the deposit and dissemination of scientific research documents, whether they are published or not. The documents may come from teaching and research institutions in France or abroad, or from public or private research centers.
L'archive ouverte pluridisciplinaire HAL, est destinée au dépôt et à la diffusion de documents scientifiques de niveau recherche, publiés ou non, émanant des établissements d'enseignement et de recherche français ou étrangers, des laboratoires publics ou privés. 


\title{
$\beta$-eudesmol, a sesquiterpene from Teucrium ramosissimum, inhibits superoxide production, proliferation, adhesion and migration of human tumor cell
}

\author{
Mohamed Ben Sghaier ${ }^{\mathrm{a}, *}$, Mohamed Mousslim ${ }^{\mathrm{b}, \mathrm{c}}$, Alessandra Pagano ${ }^{\mathrm{b}, \mathrm{c}}$, \\ Youssef Ammari ${ }^{\text {a }}$, José Luis ${ }^{b, c}$, Hervé Kovacic ${ }^{\text {b,c }}$ \\ a Laboratory for Forest Ecology, National Institute for Research in Rural Engineering, Water and Forests, University of carthage, BP 10, 2080 Ariana, Tunisie \\ ${ }^{\mathrm{b}}$ Centre de Recherche en Oncologie Biologique et Oncopharmacologie (CRO2), INSERM UMR 911, Faculté de Pharmacie, Marseille, France \\ ${ }^{c}$ Aix-Marseille Université, France
}

\section{A R T I C L E I N F O}

\section{Article history:}

Received 29 April 2016

Received in revised form 14 July 2016

Accepted 29 July 2016

Available online 30 July 2016

\section{Keywords:}

Reactive oxygen species

NADPH oxidase

$\beta$-eudesmol

Proliferation

Adhesion

Migration

\begin{abstract}
A B S T R A C T
Reactive oxygen species are well-known mediators of various biological responses. Recently, new homologues of the catalytic subunit of NADPH oxidase have been discovered in non phagocytic cells. These new homologues (Nox1-Nox5) produce low levels of superoxides compared to the phagocytic homologue Nox2/gp91phox. In this study we examined the effect of $\beta$-eudesmol, a sesquiterpenoid alcohol isolated from Teucrium ramosissimum leaves, on proliferation, superoxide anion production, adhesion and migration of human lung (A549) and colon (HT29 and Caco-2) cancer cell lines. Proliferation of tumor cells was inhibited by $\beta$-eudesmol. It also significantly inhibited superoxide production in A549 cells. Furthermore, $\beta$-eudesmol inhibited adhesion and migration of A549 and HT29 cell. These results demonstrate that $\beta$-eudesmol may be a novel anticancer agent for the treatment of lung and colon cancer by different ways: by inhibition of superoxide production or by blocking proliferation, adhesion and migration.
\end{abstract}

(c) 2016 Elsevier B.V. All rights reserved.

\section{Introduction}

Oxidative stress is a characteristic feature of many cancers, and has been implicated in cancer development and progression (Rodrigues et al., 2014). However, most anticancer drugs kill their target cells, at least in part, through the generation of elevated amounts of intracellular ROS (Benhar et al., 2001). ROS, such as superoxide anions $\left(\mathrm{O}_{2}^{-}\right)$and hydrogen peroxide $\left(\mathrm{H}_{2} \mathrm{O}_{2}\right)$ are produced by mitochondria, peroxisome, cytochrome P-450 and NADPH oxidase (D'Autreaux and Toledano, 2007) generated through the increased metabolic activity of cancer cells, enhanced signaling pathways or mitochondrial dysfunction (Liou and Storz, 2010). Superoxide anions are converted to $\mathrm{H}_{2} \mathrm{O}_{2}$ by the enzyme superoxide dismutase. Unlike mitochondria, peroxisome and cytochrome P-450, which generate ROS as normal metabolic by-products, specific enzymes such as NADPH oxidases generate ROS as a primary function (Bedard and Krause, 2007). Nox1 is a catalytic subunit of a NADPH oxidase complex initially identified in

\footnotetext{
* Corresponding author.

E-mail address: medbensghaier.inrgref@gmail.com (M. Ben Sghaier).
}

colonic adenocarcinoma cell lines (Banfi et al., 1999). Nox1 induces the production of low amount of superoxide and controls cell proliferation, apoptosis, migration and innate immune response (Sadok et al., 2008). Overexpression of Nox1 in colon seems to be related to tumor progression, particularly in K-Ras mutated cells (Laurent et al., 2008).

Cancer cells move within tissues during invasion and metastasis by their own motility, and control of cancer cell migration is an important problem in tumor treatment. Directed cell migration is a critical feature of various physiological and pathological processes, including development, wound healing, immunity, angiogenesis, and metastasis (Yamazaki et al., 2005). Cell migration results in dynamic interactions between the cell and the extracellular matrix (ECM). These interactions are partly mediated by integrins, a widely expressed family of cell surface adhesion receptors. Integrins are the major metazoan receptors for cell adhesion to extracellular matrix proteins and, in vertebrates, also play important roles in certain cell-cell adhesions. In addition to their roles in adhesion to ECM ligands or counterreceptors on adjacent cells, integrins serve as transmembrane mechanical links from those extracellular contacts to the cytoskeleton inside cells. 
In part related to the integrin-mediated assembly of cytoskeletal linkages, ligation of integrins also triggers a large variety of signal transduction events that serve to modulate many aspects of cell behavior including proliferation, survival/apoptosis, shape, polarity, motility, gene expression, and differentiation (Hynes, 2002).

We have previously reported that extracts of Teucrium ramosissimum inhibited proliferation of human cancer cells (K562) and enhanced antioxidant and anti-inflammatory activities in vitro (Ben Sghaier et al., 2011a,b). The leaves of T. ramosissimum contain sesquiterpenoid alcohols, such as $\beta$-eudesmol that is known to have various unique effects on the nervous system. For example, we have shown that $\beta$-eudesmol acts as a channel blocker for nicotinic acetylcholine receptors at the neuromuscular junction (Kimura et al., 1991a,b). In addition, Obara et al. (2002) have reported that $\beta$-eudesmol induces neurite outgrowth in rat pheochromocytoma PC12 cells via an increase in the intracellular $\mathrm{Ca}^{2+}$ concentration. Tsuneki et al. (2005) and Ma et al. (2008) also reported the antiangiogenic potential of $\beta$-eudesmol using in vitro and in vivo experimental models. In the present study, we investigated the potential antiproliferative and antioxidant activities of $\beta$-eudesmol in human lung (A549) and colon (HT29 and Caco-2) cancer cell lines. We also examined the effect of $\beta$-eudesmol on tumor cells adhesion and migration using several purified ECM proteins.

\section{Material and methods}

\subsection{Chemicals and reagents}

$\beta$-eudesmol was obtained from chloroform extract of the aerial part of T. ramosissimum (Ben Sghaier et al., 2011b). Dulbecco's modified Eagle's medium (DMEM) and RPMI 1640 medium were purchased from Lonza (Levallois-Perret, France). Penicillin, streptomycin, fetal bovine serum (FBS), trypsin-EDTA, L-glutamine, and sodium pyruvate were purchased from GIBCO (CergyPontoise, France). Methylthiazolyldiphenyl-tetrazolium bromide (MTT), lucigenin, poly-L-lysine, human fibrinogen and mouse laminin-1 were purchased from Sigma (St Quentin Fallavier, France). Rat type I collagen was from Upstate (Lake Placid, NY, USA) and human fibronectin was from Millipore (St Quentin en Yvelines, France). Human vitronectin was purified according to Yatogho et al. (1988).

\subsection{Tumors cell lines and culture conditions}

The cell lines used in this study was purchased from American type culture Collection Company. Human lung (A549) cells were cultured in RPMI 1640 medium, colon (HT29 and Caco-2) cells were maintained in Dulbecco's modified Eagle's medium (DMEM), all the media were supplemented with $10 \%$ fetal bovine serum (FBS), supplemented with $2 \mathrm{mM}$ L-glutamine and $1 \%$ sodium pyruvate and were maintained at $37{ }^{\circ} \mathrm{C}$ in a humidified atmosphere with $5 \% \mathrm{CO}_{2}$.

\subsection{Cell proliferation assay}

MTT assays determine the ability of viable cells to convert a soluble yellow tetrazolium salt into insoluble purple formazan crystals by the mitochondrial dehydrogenase enzymes. For each cell line, $70 \%$ confluent cell culture flask was trypsinized and cells were seeded in 96-well plates at a density of 5000 cells per well in the appropriate complete media. $24 \mathrm{~h}$ after seeding, the cells were treated with the different compounds or control vehicle solution (DMSO $0.1 \%$ in phosphate-buffered saline). $72 \mathrm{~h}$ after treatment, cells were exposed to $0.5 \mathrm{mg} / \mathrm{ml}$ of MTT for $3 \mathrm{~h}$ at $37^{\circ} \mathrm{C}$ in the appropriate complete medium. Medium and MTT were removed and after solubilization in dimethylsulfoxide (DMSO), the amount of insoluble formazan crystals was evaluated by measuring the optical density at $550 \mathrm{~nm}$. Each condition was performed in triplicate and measurements were corrected from the optical density of MTT alone and expressed relative to the non-treated conditions. Determination of the concentration inhibiting $50 \%$ of cell viability $\left(\mathrm{IC}_{50}\right)$ was performed according to the methods of Chou (2006). Briefly, the fraction of cell affected $\left(F_{a}\right)$ and the fraction of cell unaffected $\left(\mathrm{F}_{\mathrm{u}}\right)$ relative to 1 were determined from the viability assay. The log of $\left(\mathrm{F}_{\mathrm{a}} / \mathrm{F}_{\mathrm{u}}\right)$ was plotted against the log of concentration for each compound and $\log$ of $\mathrm{IC}_{50}$ was determined at the $\mathrm{y}$-intercept. Standard error was evaluated through the $95 \%$ confidence interval.

\subsection{Measurement of ROS}

ROS generation was measured by lucigenin chemiluminescence detecting superoxide ions (Irani et al., 1997). After incubation of cells for the desired time with drugs in 96 -well plates $\left(50 \times 10^{3}\right.$ cells/well), luminescence was detected by a Fluoroscan Ascent FL fluorimeter (Labsystems, France). The detected signal was assessed at each minute over the course of $45 \mathrm{~min}$. Results represent the integration of the signal for $45 \mathrm{~min}$ and is associated with the intermediate time of measurement. All measurements were performed at $37^{\circ} \mathrm{C}$ and results are expressed as total reactive oxygen species measurements which represent the difference of reactive oxygen species production measured in untreated control.

$24 \mathrm{~h}$ after passage, cells were serum-starved for $48 \mathrm{~h}$, trypsinized and seeded in 96-well plates at a density of 50,000 cells/well in the appropriate complete media. Cells were incubated $30 \mathrm{~min}$ with vehicle $(0.1 \%$ DMSO) or the following regulators: NADPH oxidase inhibitor diphenylene iodonium (DPI) $(10 \mu \mathrm{M})$, cyclooxygenase inhibitor indomethacin $(10 \mu \mathrm{M})$, cytochrome P450 inhibitor aminobenzotriazol $(1 \mathrm{mM})$, mitochondrial inhibitor rotenone $(2 \mu \mathrm{M})$ and xanthine oxidase inhibitor allopuranol ( $1 \mathrm{mM})$. All measurements were performed at $37^{\circ} \mathrm{C}$. Results are expressed as total reactive oxygen species measurements. Results represent the percentage variation relative to untreated control.

\subsection{Cell adhesion assay}

Adhesion assays were performed as previously described (Bazaa et al., 2009). Briefly, flat bottom 96-well microtiter plates were coated with one of the following purified ECM proteins: fibronectin $(10 \mu \mathrm{g} / \mathrm{ml})$, vitronectin $(10 \mu \mathrm{g} / \mathrm{ml})$, laminin $1(10 \mu \mathrm{g} / \mathrm{ml})$, fibrinogen $(50 \mu \mathrm{g} / \mathrm{ml})$, collagen type I or IV $(10 \mu \mathrm{g} / \mathrm{ml})$ and were blocked with BSA. Cells were harvested in single cell suspension and resuspended in DMEM and RPMI containing 0.2\% BSA (adhesion buffer) in the presence or absence of $\beta$-eudesmol for $30 \mathrm{~min}$ at room temperature. Cells were then added to coated wells in a volume of $50 \mu \mathrm{l}$ $\left(10^{6}\right.$ cells $\left./ \mathrm{ml}\right)$ and allowed to adhere to the substrate for $1 \mathrm{~h}$ (A549 cells) or $2 \mathrm{~h}$ (HT29 cells) at $37^{\circ} \mathrm{C}$. Unattached cells were removed by gently washing three times with adhesion buffer. Residual attached cells were fixed by $1 \%$ glutaraldehyde, stained by $0.1 \%$ crystal violet and lysed with $1 \%$ SDS. Absorbance was then measured at $600 \mathrm{~nm}$ by a microplate reader.

\subsection{Cell migration assays}

In vitro cell migration assays were performed using modified Boyden chambers (NeuroProbe Inc, Bethesda, MD, USA) as previously described (Delamarre et al., 2009). Briefly, membranes were coated with fibronectin or collagen type IV $(10 \mu \mathrm{g} / \mathrm{ml})$ for $2 \mathrm{~h}$ at $37^{\circ} \mathrm{C}$ and blocked with a solution of $0.1 \% \mathrm{BSA} / \mathrm{PBS}$. Cells harvested as a single cell suspension, were added to precoated membranes and allowed to migrate for $5 \mathrm{~h}$ at $37^{\circ} \mathrm{C}$. Cells were stained by $0.1 \%$ crystal violet and migration was quantified by measuring the absorbance at $600 \mathrm{~nm}$. 


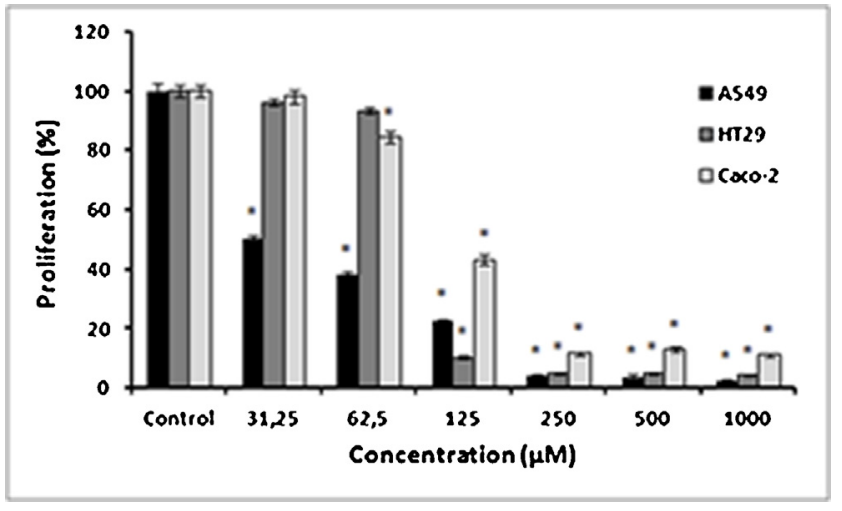

Fig. 1. Inhibitory effect of $\beta$-eudesmol on the proliferation of human lung and colon cancer cells.

Human lung (A549) and colon (HT29 and Caco-2) cancer cells, plated at $5 \times 10^{3}$ cells per well, were cultured for 3 days in the absence and the presence of $\beta$-eudesmol at the indicated concentrations. Control cells were treated with 0.1\% DMSO (vehicle). Data are means \pm S.E., $n=3$ per group.

A549 and HT29 cells migration was assayed by wound/healing assay as described previously (Tsuneki et al., 2005). Confluent cells in 35-mm-diameter dishes were damaged by scraping with a sterile pipette tip (500 $\mathrm{mm}$ in diameter). The cultures were washed twice with PBS to remove cellular debris. Vehicle control and various concentrations of $\beta$-eudesmol were added to the respective wells for the indicated times. The migration of HT29 cells into the denuded area was promoted by stimulation with phorbol 12-myristate 13-acetate (PMA). After $18 \mathrm{~h}$, the cells that had migrated into the denuded area were photographed using an Olympus inverted microscope. Migration was quantified by measuring the covered surface.

\subsection{Statistical analysis}

Results are expressed as means \pm S.E. from at least three independent experiments. Statistical analysis was performed using unpaired Student's test. The value of $P<0.05$ was considered statistically significant.

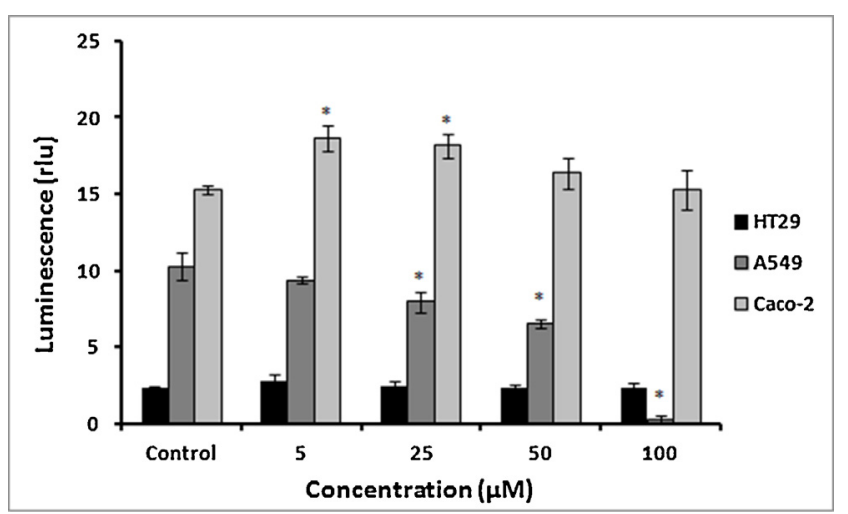

Fig. 2. Effect of $\beta$-eudesmol on the production of $\mathrm{O}_{2}{ }^{-}$by human lung and colon cancer cells.

Cells were plated at $50 \times 10^{3}$ cell/well. Production of $\mathrm{O}_{2}{ }^{-}$was determined by lucigenin luminescence as described in the Methods section. $\beta$-eudesmol significantly decreased $\mathrm{O}_{2}{ }^{-}$production in the $\mathrm{A} 549$ cell compared with untreated cells $\left({ }^{*} \mathrm{P}<0.05\right)$. Data are means \pm S.E. from at least three independent experiments performed in triplicate. Results are expressed as total ROS measurements. Results represent the percentage variation relative to untreated control.

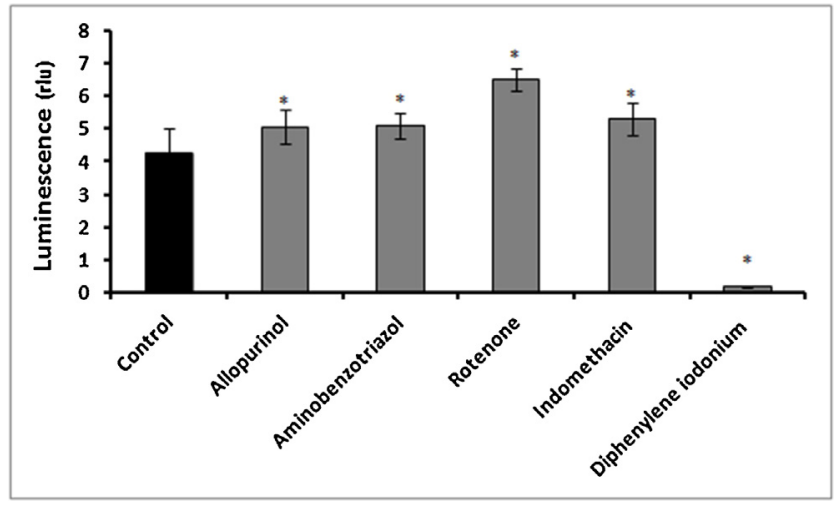

Fig. 3. NADPH oxidase mediates $\mathrm{O}_{2}{ }^{-}$production in Human lung (A549) cell.

$\mathrm{O}_{2}^{-}$production was evaluated by lucigenin luminescence. Cells were treated with different inhibitors for $0.5 \mathrm{~h}$ and measurements were taken. Results represent means \pm S.E of triplicate samples; *indicates statistically significant results compared to control $(\mathrm{p}<0.05)$. Results are expressed as total ROS measurements. Results represent the percentage variation relative to untreated control.

\section{Results}

\subsection{Inhibitory effect of $\beta$-eudesmol on cell proliferation}

The effect on cell proliferation of the tested compound was performed on different cancer cell lines using MTT assay over a $72 \mathrm{~h}$

A

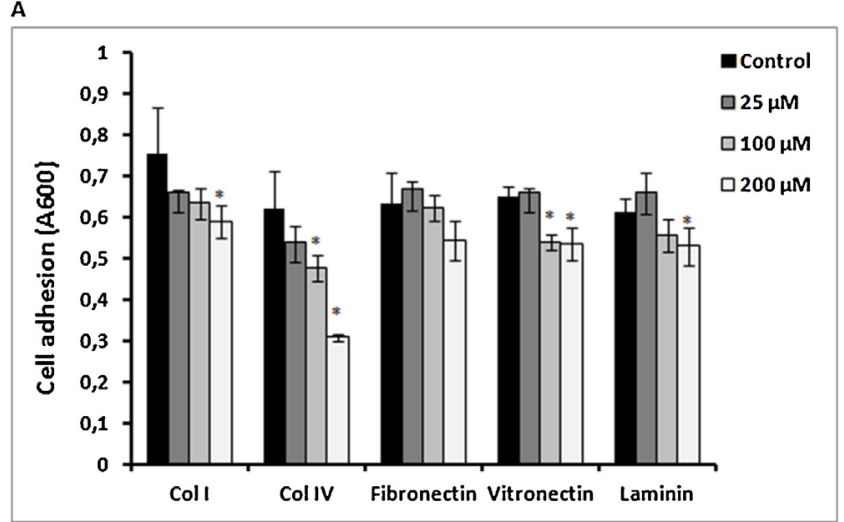

B

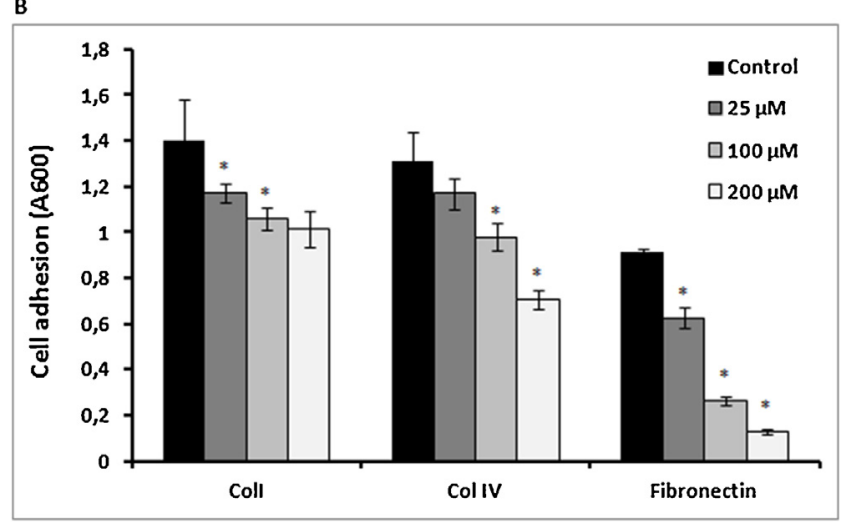

Fig. 4. $\beta$-eudesmol inhibits cell adhesion.

A549 (A) or HT29 (B) cells were preincubated without or with 25,100 or $200 \mu \mathrm{M}$ $\beta$-eudesmol for $30 \mathrm{~min}$ at room temperature. Cells were then added to 96 -well microtiter plates coated with fibronectin $(10 \mu \mathrm{g} / \mathrm{ml})$, vitronectin $(10 \mu \mathrm{g} / \mathrm{ml})$, laminin $1(10 \mu \mathrm{g} / \mathrm{ml})$, fibrinogen $(50 \mu \mathrm{g} / \mathrm{ml})$, collagen type I and IV $(10 \mu \mathrm{g} / \mathrm{ml})$ and allowed to adhere for $1 \mathrm{~h}$ (A549) or $2 \mathrm{~h}$ (HT29) at $37^{\circ} \mathrm{C}$. After washing, adherent cells were stained with crystal violet, solubilized by SDS and absorbance was measured at $600 \mathrm{~nm}$. Data shown are means $( \pm$ S.E) of at least three independent experiments and expressed as a percentage of adhesion. *indicates statistically significant results compared to control $(\mathrm{p}<0.05)$ 


\section{A (Col IV)}

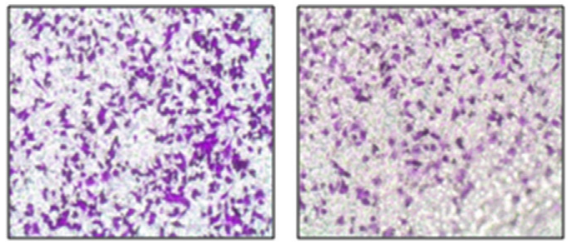

Control

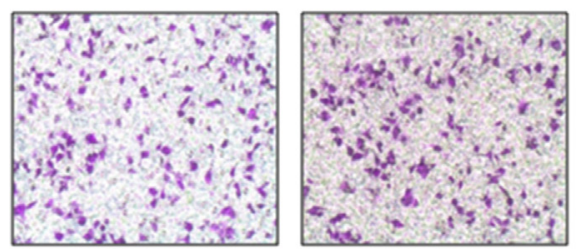

\section{$\beta$-eudesmol (100 $\mu \mathrm{M})$}
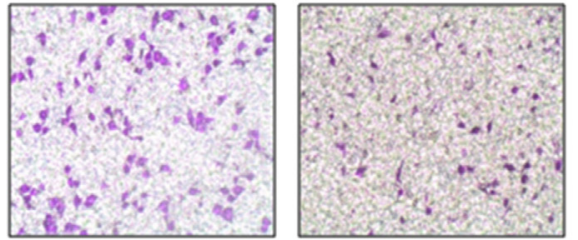

$\beta$-eudesmol (200 $\mu \mathrm{M})$
B

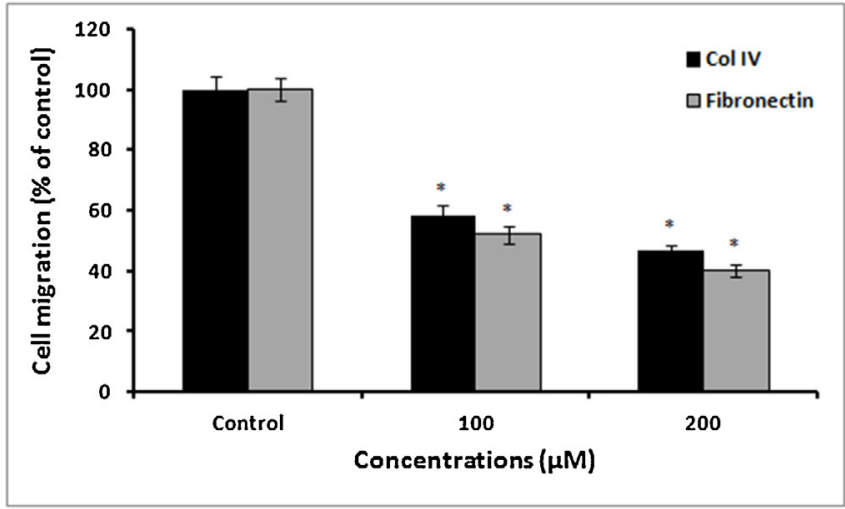

C

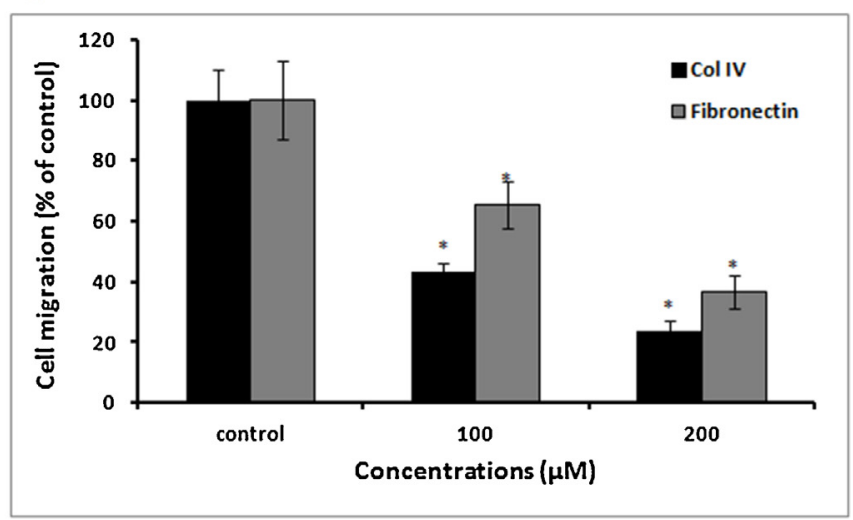

Fig. 5. $\beta$-eudesmol inhibits cell migration in Boyden chamber.

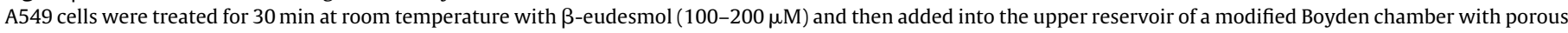

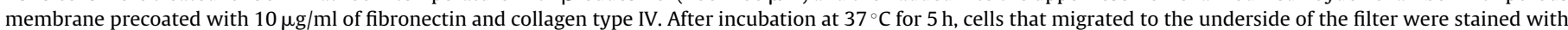

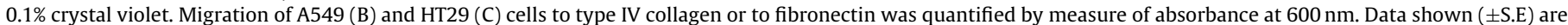
from one experiment representative of three performed in triplicate. *indicates statistically significant results compared to control ( $\mathrm{p}<0.05$ ).

period. Viability percentage (\%) tended to decrease in the presence of $\beta$-eudesmol at concentrations between 31.25 and $1000 \mu \mathrm{M}$, with A549 lung cells being more sensitive to compound than colon cancer cells HT29 and Caco-2 (Fig. 1). Indeed, $\beta$-eudesmol significantly inhibited the proliferation of A549, HT29 and Caco-2 cells in a concentration-dependent manner with $\mathrm{IC}_{50} \mathrm{~S}$ of $38 \mu \mathrm{M}, 97 \mu \mathrm{M}$ and $107 \mu \mathrm{M}$ respectively.

\section{2. $\beta$-eudesmol inhibits NADPH oxidase-dependent superoxide production}

Usually, tumor cells have high ROS levels. Moreover, some tumor cells, such as human colon adenocarcinoma HT29 cells and human lung A549 cells can even produce ROS. We therefore investigated the effect of $\beta$-eudesmol in superoxide anion production. As shown in Fig. 2, a 30 min pretreatment of A549 cells with 5-100 $\mu \mathrm{M}$ $\beta$-eudesmol diminished the level of ROS production, the reduction of superoxide anion production reached $98 \%$ at the highest concentration $(100 \mu \mathrm{M})$. On the contrary, $\beta$-eudesmol had no significant effect on ROS production in HT29 or Caco-2 cells (Fig. 2).

Several intracellular sources contribute to the production of ROS, including cyclooxygenases, cytochrome P450, lipoxygenases, mitochondrial respiration, xanthine oxidase (Hordijk, 2006), and NADPH oxidase (Suh et al., 1999). We used a variety of inhibitors to identify the source of $\mathrm{O}_{2}^{-}$production, and showed that DPI ( $10 \mu \mathrm{M}, \mathrm{NADPH}$ oxidase inhibitor) inhibited $96 \%$ of the $\mathrm{O}_{2}{ }^{-}$production in A549 cell. In contrast, rotenone $(2 \mu \mathrm{M})$, allopurinol ( $1 \mathrm{mM})$, indomethacin $(10 \mu \mathrm{M})$ or aminobenzotriazol $(1 \mathrm{mM})$ did not affect $\mathrm{O}_{2}{ }^{-}$production (Fig. 3 ).

\section{3. $\beta$-eudesmol affects adhesion of A549 and HT29 cells}

It has long been known that most cell types require attachment to grow. As $\beta$-eudesmol inhibited tumor cell proliferation, we investigated whether it can act through blocking cell attachment. In order to investigate the $\beta$-eudesmol effects on A549 and HT29 cells, we first performed cell adhesion assays using a large array of purified ECM proteins.

As illustrated in Fig. $4 A$ and $B$, the effect of $\beta$-eudesmol depended on the cell line. In the case of A549 cells, only attachment of to type IV collagen was affected by $\beta$-eudesmol in a dose-dependent manner (Fig. 4A). On the contrary, $\beta$-eudesmol readily impaired attachment of HT29 cells to fibronectin and with less potency to type I and IV collagens no effect was observed on vitronectin or on laminin (Fig. 4B).

\section{4. $\beta$-eudesmol inhibits tumor cells migration}

Cell migration requires the formation of new attachments to the heading edge of the cell. We therefore first tested the ability of $\beta$-eudesmol to inhibit integrin-dependent migration of A549 and HT29 cells using haptotaxis assays in modified Boyden chambers. As shown in Fig. 5A and B, $\beta$-eudesmol dramatically reduced A549 cells migration towards type IV collagen and fibronectin. This effect was dose-dependent with of $54 \%$ and $60 \%$ inhibition for type IV 
A

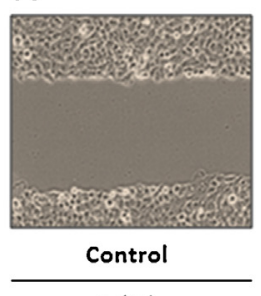

$t(0)$

B
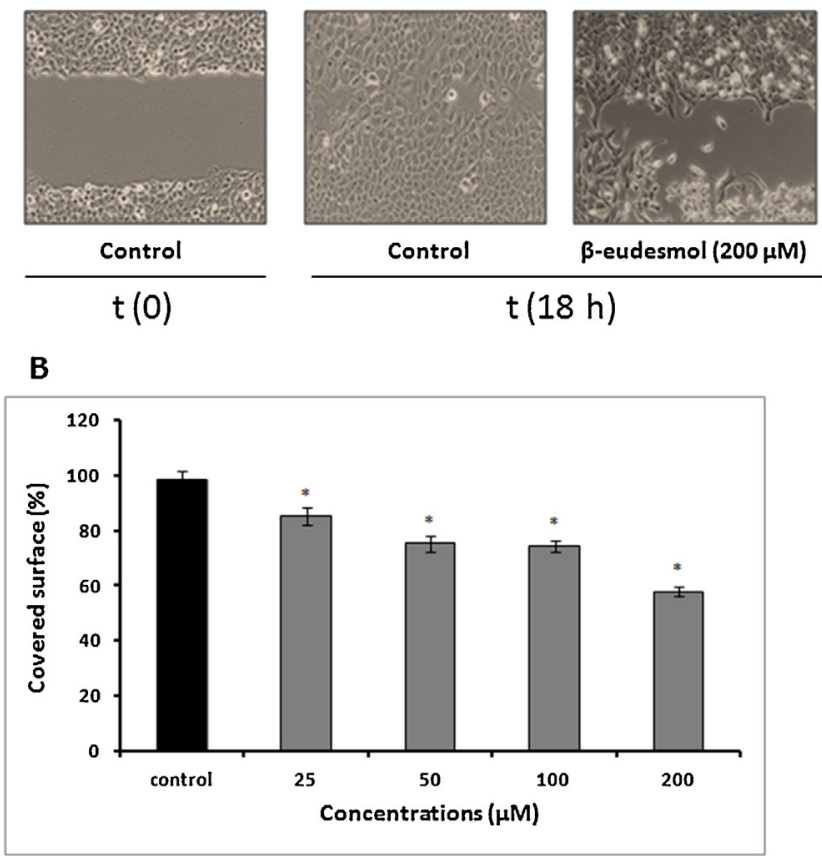

Control

$\beta$-eudesmol (200 $\mu \mathrm{M})$

$t(18 h)$

C

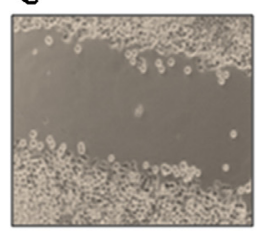

Control

$t(0)$

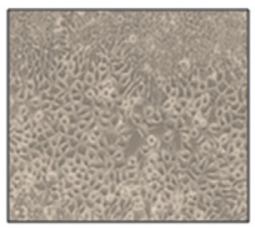

Control

$t(18 h)$

D

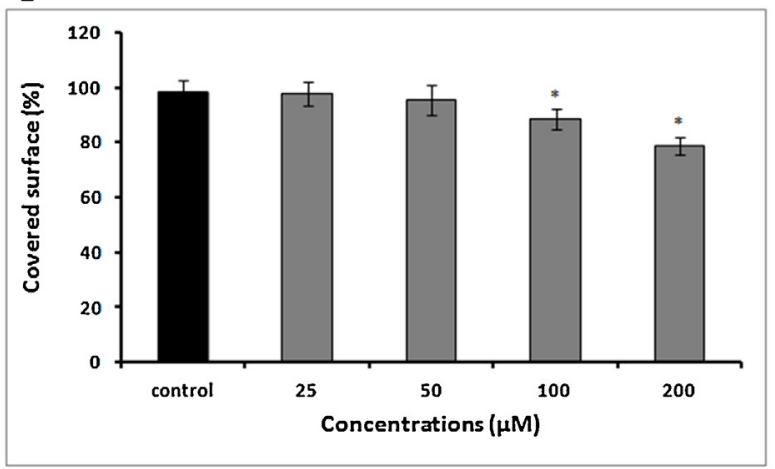

Fig. 6. $\beta$-eudesmol inhibits cell migration in wound-healing assays.

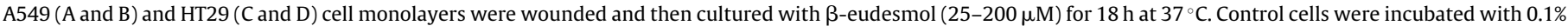

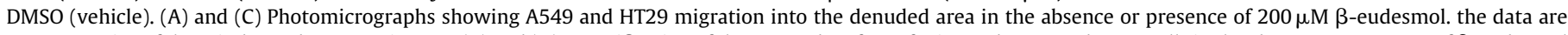

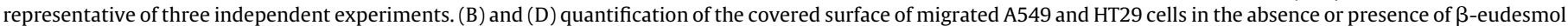
$(25-200 \mu M)$. Data are means \pm S.E; $n=3$ per group. *indicates statistically significant results compared to control ( $p<0.05)$.

collagen and fibronectin respectively in the presence of $200 \mu \mathrm{M}$ $\beta$-eudesmol.

$\beta$-eudesmol also affected migration of HT29 cell line (Fig. 5C). The inhibition of migration in the presence of $200 \mu \mathrm{M} \beta$-eudesmol reached $76 \%$ and $63 \%$ for type IV collagen and fibronectin respectively.

The effect of $\beta$-eudesmol was further confirmed by using wound/healing assay. Scrape damaged A549 and HT29 cell monolayers were incubated in the presence of $\beta$-eudesmol $(25-200 \mu \mathrm{M})$ for $18 \mathrm{~h}$. $\beta$-eudesmol significantly inhibited the migration of both A549 (Fig. 6A and B) and HT29 (Fig. 6C and D) cells in a concentration-dependent manner.

\section{Discussion}

Several bioactive compounds from natural plants have been investigated for their anticancer activities by inducing cell cycle arrest, inhibit angiogenesis and activate apoptosis pathways, resulting in inhibition of cell proliferation, progression and metastasis of cancer. Thus, although information derived from clinical trials is still insufficient, the number of significant in vitro and in vivo studies has increased providing evidences of the great promise of natural products and plants extracts for clinical use (Cravotto et al., 2010). $\beta$-eudesmol, one of the major representatives of sesquiterpenes, is present in many natural plants (Ben Sghaier et al., 2011a), and has been shown to inhibit angiogenesis, tumor cell proliferation and to enhance antioxidant activity (Ben Sghaier et al., 2011a; Tsuneki et al., 2005; Ma et al., 2008). In the present study, we show for the first time to our knowledge, that $\beta$-eudesmol also inhibits proliferation, adhesion and migration of various tumor cell lines.

Proliferation of human lung (A549) and colon (HT29 and Caco-2) cancer cell lines was significantly inhibited by $\beta$-eudesmol over a concentration range of $31.25-500 \mu \mathrm{M}$ in a dose-dependent manner. Such an inhibitory effect has previously been observed on endothelial cells (PBMEC, HDMEC and HUVEC) and HeLa, SGC-7901, BEL-7402 and K562 human cell lines (Ben Sghaier et al., 2011a; Tsuneki et al., 2005; Ma et al., 2008). The effect of $\beta$-eudesmol on growth medium-stimulated proliferation is due to inhibition of DNA synthesis in PBMEC (Tsuneki et al., 2005).

Mitogen-activated protein kinase (MAPK) pathways are evolutionarily conserved kinase modules that link extracellular signals to the machinery that controls fundamental cellular processes such as growth, proliferation, differentiation, migration and apoptosis (Dhillon et al., 2007). Tsuneki et al. (2005) found that activation of ERK1/2 induced by bFGF and VEGF was blocked by $\beta$-eudesmol in endothelial cells, whereas $\beta$-eudesmol had no effect on the activation of p38 MAP kinase. The concentrations needed for inhibition of ERKs were similar to those inhibiting endothelial cell proliferation, migration, and tube formation. Therefore, the $\beta$-eudesmol-induced inhibition of proliferation may be, at least in part, due to blockade of the ERK signaling pathway (Tsuneki et al., 2005). It is thus likely that the anti-proliferative effect of $\beta$-eudesmol we observed in the present study may be due to the inhibition of ERK signaling. Supplementary investigations are necessary to establish the target of $\beta$-eudesmol and to reveal the specific mechanism by which it inhibits cell proliferation.

Cancer cells show increased sensitivity to oxidative stress. This observation was the basis for developing a new targeted therapy strategy. In the present study, we confirmed the scavenging effect of $\beta$-eudesmol on ROS in A549 cells. However, $\beta$-eudesmol had no effect on the reactive oxygen species production by HT29 and Caco- 2 cells. In addition, by using a variety of inhibitors we identified the source of $\mathrm{O}_{2}{ }^{-}$production as the NADPH oxidases. For this reason, increasing attention has been focused on the possibility that compounds acting specifically on ROS production by the Nox's could serve as efficacious therapeutic agents (Drummond et al., 2011). A549 cells significantly express Nox1, Nox2, Nox4, Duox1 and Duox2 (Kolarova et al., 2010), HT29 cells only express Nox1 and Caco-2 cells express Nox1 and Nox5 (Dahan et al., 2009). Based 
on the obtained results, we can hypothesise that $\beta$-eudesmol might act directly or indirectly on Nox2 to inhibit superoxide production in A549 cell.

Cell adhesion is considered a serious problem in many biological phenomena such as development, tissue structure maintenance, angiogenesis, and tumor metastasis. The interactions between cancer cells and extracellular matrix (ECM) proteins, such as collagens, fibronectin, and laminin are involved in each of the events of the metastatic cascade (Rosso et al., 2004). The major group of cell surface adhesion molecules that influence cell-matrix adhesion is integrins. However, more clinical studies are needed for the exploration of new anti-integrin agents and progress of therapies.

In the present study we demonstrated that $\beta$-eudesmol affected adhesion of HT29 cells mainly on fibronectin through the integrin $\alpha v \beta 6$, the unique fibronectin receptor in this cell line. This epithelial-specific integrin is usually not detectable on normal adult epithelia, but is up-regulated during tissue remodeling, including wound healing and carcinogenesis (Thomas et al., 2001).

In a previous study reported by Tsuneki et al. (2005), $\beta$-eudesmol was shown no significant influence on HUVEC attachment to fibronectin. The difference in the response to $\beta$-eudesmol between HT29 cells and HUVECs may be explained by their attachment to fibronectin through different receptors, respectively integrins $\alpha v \beta 6$ and $\alpha 5 \beta 1$.

The integrin $\alpha v \beta 6$ of HT29 does not require activation to mediate ligand binding (Rigot et al., 1998). However, treatment of cells by $\beta$-eudesmol could lead to the suppression of the constitutive integrin activation.

The increasing level expression of $\alpha \mathrm{v}$ integrins stimulates the adhesion and migration of tumor cells. Inhibition of this expression represents an effective approach for the control and the prevention of cancer. Accordingly, various molecules targeting $\alpha \mathrm{v}$ integrins, such as RGD peptides or disintegrins, are now in clinical trials (Kenny et al., 2008). In addition, understanding the consequences of $\alpha \mathrm{v}$ integrin inhibition is essential since $\alpha \mathrm{v}$ integrins may associate with and modify the function of several bioactive molecules.

Cell migration is an important part of the metastatic process and $\beta$-eudesmol was shown to have a role in adhesion, we therefore investigated whether $\beta$-eudesmol could be implicated in the migration of A549 and HT29 cells. The inhibitory effect of $\beta$ eudesmol on cell migration is likely due to the reduced attachment to ECM proteins observed in the presence of the sesquiterpene. The same effect was observed with glabridin against A549 cells (Tsai et al., 2010).

\section{Conclusion}

To summarize, we have provided evidence demonstrating that $\beta$-eudesmol inhibits cancer cell proliferation, adhesion and migration. Therefore, $\beta$-eudesmol is a potentially specific Nox inhibitor agent in the treatment of human lung carcinoma, suggesting that this compound may aid the development of therapeutic drugs for cancer diseases.

\section{Conflict of interest}

The authors have declared that there is no conflict of interests.

\section{Acknowledgments}

We acknowledge AVERROES program for the financial support of this study. The authors acknowledge Pr. Boukataya Samir (English teacher at the Faculty of Dental Medecine, Tunisia) for English editing.

\section{References}

Banfi, B., Schrenzel, J., Nusse, O., Lew, D.P., Ligeti, E., Krause, K.H., et al., 1999. A novel $\mathrm{H}(+)$ conductance in eosinophils: unique characteristics and absence in chronic granulomatous disease. J. Exp. Med. 190, 183-194.

Bazaa, A., Luis, J., Srairi-Abid, N., Kallech-Ziri, O., Kessentini-Zouari, R., Defilles, C., et al., 2009. MVL-PLA2, a phospholipase A2 from Macrovipera lebetina transmediterranea venom, inhibits tumor cells adhesion and migration. Matrix Biol. 28, 188-193.

Bedard, K., Krause, K.H., 2007. The NOX family of ROS-generating NADPH oxidases: physiology and pathophysiology. Physiol. Rev. 87, 245-313.

Ben Sghaier, M., Harizi, H., Louhichi, T., Krifa, M., Ghedira, K., Chekir-Ghedira, L., 2011a. Anti-inflammatory and antiulcerogenic activities of leaf extracts and sesquiterpene from Teucrium ramosissimum (Lamiaceae). Immunopharmacol. Immunotoxicol. 33 (4), 656-662.

Ben Sghaier, M., Skandrani, I., Nasr, N., Dijoux Franca, M.G., Chekir-Ghedira, L., Ghedira, K., 2011b. Flavonoids and sesquiterpenes from Tecurium ramosissimum promote antiproliferation of human cancer cells and enhance antioxidant activity: a structure-activity relationship study. Environ. Toxicol. Pharmacol. 32, 336--348.

Benhar, M., Dalyot, I., Engelberg, D., Levitzki, A., 2001. Enhanced ROS production in oncogenically transformed cells potentiates c-Jun N-terminal kinase and p38 mitogen-activated protein kinase activation and sensitization to genotoxic stress. Mol. Cell Biol. 21, 6913-6926.

Chou, T.C., 2006. Theoretical basis, experimental design, and computerized simulation of synergism and antagonism in drug combination studies. Pharmacol. Rev. 58, 621-681.

Cravotto, G., Boffa, L., Genzini, L., Garella, D., 2010. Phytotherapeutics: an evaluation of the 1000 plants. J. Clin. Pharm. Ther. 35 (1), 11-48.

D’Autreaux, B., Toledano, M.B., 2007. ROS as signalling molecules: mechanisms that generate specificity in ROS homeostasis. Nat. Rev. Mol. Cell Biol. 8, 813-824.

Dahan, L., Sadok, A., Formento, J.L., Seitz, J.F., Kovacic, H., 2009. Modulation of cellular redox state underlies antagonism between oxaliplatin and cetuximab in human colorectal cancer cell lines. Brit. J. Pharmacol. 158, 610-620.

Delamarre, E., Taboubi, S., Mathieu, S., Berenguer, C., Rigot, V., Lissitzky, J.C., et al., 2009. Expression of integrin alpha6beta1 enhances tumorigenesis in glioma cells. Am. J. Pathol. 175, 844-855.

Dhillon, A.S., Hagan, S., Rath, O., Kolch, W., 2007. MAP kinase signalling pathways in cancer. Oncogene 26, 3279-3290.

Drummond, G.R., Selemidis, S., Griendling, K.K., Sobey, C.G., 2011. Combating oxidative stress in vascular disease: NADPH oxidases as therapeutic targets. Nat. Rev. Drug Discov. 10, 453-471.

Hordijk, P.L., 2006. Regulation of NADPH oxidases: the role of Rac proteins. Circ. Res. 98, 453-462.

Hynes, R.O., 2002. Integrins: bidirectional allosteric signaling machines. Cell 110 673-687.

Irani, K., Xia, Y., Zweier, J.L., Sollott, S.J., Der, C.J., Fearon, E.R., et al., 1997. Mitogenic signaling mediated by oxidants in Ras transformed fibroblasts. Science 275, 1649-1652.

Kenny, L.M., Coombes, R.C., Oulie, I., Contractor, K.B., Miller, M., Spinks, T.J., 2008 Phase I trial of the positron-emitting Arg-Gly-Asp (RGD) peptide radioligand 18F-AH111585 in breast cancer patients. J. Nucl. Med. 49, 879-886.

Kimura, M., Kimura, I., Kondoh, T., Tsuneki, H., 1991a. Noncontractile acetylcholine receptor-operated Ca++ mobilization: suppression of activation by open channel blockers and acceleration of desensitization by closed channel blockers in mouse diaphragm muscle. J. Pharmacol. Exp. Ther. 256, 18-23.

Kimura, M., Nojima, H., Muroi, M., Kimura, I., 1991b. Mechanism of the blocking action of $\beta$-eudesmol on the nicotinic acetylcholine receptor channel in mouse skeletal muscles. Neuropharmacology 30, 835-841.

Kolarova, H., Bino, L., Pejchalova, K., Kubala, L., 2010. The expression of NADPH oxidases and production of reactive oxygen species by human lung adenocarcinoma epithelial cell line A549. Folia Biol. 56, 211-217.

Laurent, E., McCoy, J.W., Macina, R.A., Liu, W., Cheng, G., Robine, S., Papkoff, J., Lambeth, J.D., 2008. Nox1 is over-expressed in human colon cancers and correlates with activating mutations in K-Ras. Int. J. Cancer 123, 100-107.

Liou, G.Y., Storz, P., 2010. Reactive oxygen species in cancer. Free Radic. Res. 44 , 479-496.

Ma, E.L., Li, Y.C., Tsuneki, H., Xiao, J.F., Xia, M.Y., Wang, M.W., et al., 2008. $\beta$-eudesmol suppresses tumour growth through inhibition of tumour neovascularisation and tumour cell proliferation. J. Asian Nat. Prod. Res. 10 (1-2), 159-167.

Obara, Y., Aoki, T., Kusano, M., Ohizumi, Y., 2002. $\beta$-eudesmol induces neurite outgrowth in rat pheochromocytoma cells accompanied by an activation of mitogen-activated protein kinase. J. Pharmacol. Exp. Ther. 301, 803-811.

Rigot, V., Lehmann, M., André, F., Daemi, N., Marvaldi, J., Luis, J., 1998. Integrin ligation and PKC activation are required for migration of colon carcinoma cells. J. Cell Sci. 111 (Pt. 20), 3119-3127.

Rodrigues, P., de Marco, G., Furriol, J., Mansego, M.L., Pineda-Alonso, M., Gonzalez-Neira, A., Martin-Escudero, J.C., Benitez, J., Lluch, A., Chaves, F.J., Eroles, P., 2014. Oxidative stress in susceptibility to breast cancer: study in Spanish population. BMC Cancer 14, 861.

Rosso, F., Giordano, A., Barbarisi, M., Barbarisi, A., 2004. From cell-ECM interactions to tissue engineering. J. Cell. Physiol. 19 (2), 174-180.

Sadok, A., Bourgarel-Rey, V., Gattacceca, F., Penel, C., Lehmann, M., Kovacic, H., 2008. Nox1-dependent superoxide production controls colon adenocarcinoma cell migration. Biochim. Biophys. Acta 1783, 23-33. 
Suh, Y.A., Arnold, R.S., Lassegue, B., Shi, J., Xu, X., Sorescu, D., et al., 1999. Cell transformation by the superoxidegenerating oxidase Mox1. Nature 401, 79-82.

Thomas, G.J., Lewis, M.P., Hart, I.R., Marshall, J.F., Speight, P.M., 2001. AlphaVbeta6 integrin promotes invasion of squamous carcinoma cells through up-regulation of matrix metalloproteinase-9. Int. J. Cancer 92, 641-650.

Tsai, Y.M., Yang, C.J., Hsu, Y.L., Wu, L.Y., Tsai, Y.C., Hung, J.Y., et al., 2010. Glabridin inhibits migration, invasion, and angiogenesis of human non-small cell lung cancer A549 cells by inhibiting the FAK/rho signaling pathway. Integr. Cancer Ther. 10 (4), 341-349.
Tsuneki, H., Ma, E.L., Kobayashi, S., Sekizaki, N., Maekawa, K., Sasaoka, T., et al., 2005. Antiangiogenic activity of $\beta$-eudesmol in vitro and in vivo. Eur. J. Pharmacol. 512, 105-115.

Yamazaki, D., Kurisu, S., Takenawa, T., 2005. Regulation of cancer cell motility through actin reorganization. Cancer Sci. 96 (7), 379-386.

Yatogho, T., Izumi, M., Kashiwagi, H., Hayashi, M., 1988. Novel purification of vitronectin from human plasma by heparin affinity chromatography. Cell Struct. Funct. 13, 281-292. 